\title{
Potency/Immunogenicity Profile of DPT Vaccines Used in the Expanded Programme on Immunization in South-East, Nigeria
}

\author{
Oli $\mathrm{AN}^{1 *}$, Agu RU², Nnadozie $\mathrm{OJ}^{3}$ and Esimone $\mathrm{CO}^{1}$
}

${ }^{1}$ Department of Pharmaceutical Microbiology and Biotechnology, Faculty of Pharmaceutical Sciences, Nnamdi Azikiwe University, Agulu Campus, Anambra State, Nigeria ${ }^{2}$ Biopharmaceutics and Drug Delivery Laboratory, College of Pharmacy, 5968 College Street, PO Box 15000, Dalhousie University, B3H 4R2, Halifax, NS, Canada ${ }^{3}$ Department of Chemical Pathology, Nnamdi Azikiwe University Teaching Hospital, Nnewi, Anambra State, Nigeria

\begin{abstract}
Objectives: This study tries to validate the DPT vaccines used in South-east Nigeria for the routine childhood immunization.
\end{abstract}

Study design: The Antibody Induction Method in mice was used. The neutralizing IgG antibody titers in a control group ( 7 mice given DPT stored at $37^{\circ} \mathrm{C}$ for 1 year) and test group ( 7 mice given DPT vaccines from the SouthEastern States of Nigeria) were compared after 30 days post-immunization using One-Way ANOVA, Bartlett's test for equal variances and Dunnett's Multiple Comparison Test.

Results: The vaccines from the States produced similar Pertussis and Tetanus antibody titers which were significantly higher than the control $(P<0.0001)$. The Diphtheria antibody titer produced by the vaccine from Enugu/ Ebonyi States was higher than the vaccines from other States. The control produced much less Diphtheria IgG antibody titer $(P<0.0001)$. The vaccines do not differ significantly from each other on the level of antibody titer (protection) and their individual protection can last for the maximum number of days needed for a repeat vaccination except for the control.

Conclusions: There is statistical difference in the antibody titer evoked by the control compared to that evoked by the vaccines from the states. The vaccines from the States show $100 \%$ potency and immunogenicity. This indicates adequate cold-chain maintenance and monitoring of South-eastern Nigeria. Continuous monitoring of efficiency of cold- chain maintenance and vaccine potency testing would translate to good vaccine strategy.

Keywords: Routine immunization; DPT vaccine; Potency/ Immunogenicity; South-east Nigeria

\section{Introduction}

Preventive medicine has been recognized to be a cheaper way of avoiding treatment cost, averting disability and preventing death and vaccines are well known for their role in such [1-3]. Because they are bio-products, they are affected by storage temperature/conditions and their potency tends to reduce with time. Childhood immunisation is one of the most important preventive health actions undertaken to promote children's health $[3,4]$. It protects them against the most dangerous childhood diseases. Potency and immunogenicity assays are essential in the quality control of vaccines for human and animal use $[5,6]$ and are integral parts in biopharmaceutical products' life cycle and development [7]. Immunogenicity studies generally provide important information with respect to optimization of adjuvant formulations (where necessary) and the evaluation of immunological characteristics of the antigen including the ability to induce functional antibodies and/ or protection from challenge [8]. While immunogenicity refers to a vaccine's ability to induce a specific immune response, potency refers to ability to induce a protective immune response [9].

DPT is a class of combination vaccines developed to provide protection against three infectious human diseases: diphtheria, pertussis (whooping cough) and tetanus. The vaccine components include diphtheria and tetanus toxoids, and killed whole Bordetella pertussis cells - the organism that causes pertussis - all adsorbed on insoluble aluminium salts that serve as adjuvants. Some other combination vaccines include the Pentavalent vaccine (a combination of five vaccines in one: diphtheria, tetanus, whooping cough, hepatitis B and Haemophilus influenza type $\mathrm{b}$ (the bacteria that causes meningitis, pneumonia and otitis)), Hexaxim [10,11] - "a new, thiomersal-free, fully liquid, hexavalent combination pediatric vaccine containing diphtheria and tetanus toxoids, acellular pertussis, inactivated poliovirus, recombinant hepatitis B virus surface antigen produced in the yeast Hansenula polymorpha, and Haemophilus influenzae type $b$ polysaccharide (polyribosylribitol phosphate) conjugated to tetanus toxoid" and MMR vaccine which give protection against measles, mumps and rubella. The pentavalent vaccine is expected to replace the current Hepatitis B and DPT vaccinations in the immunisation programme during the 6,10 and 10 week after birth and reduces the incidence of pneumonia and meningitis caused by Haemophilus influenzae type $\mathrm{b}(\mathrm{Hib})$ bacteria $[4,12,13]$.

This study evaluates, indirectly, if the DPT and Pentavalent vaccines used in routine Immunization Programme in South-east Nigeria contains sufficient quantity of antigens of suitable characteristics (quality) to induce a protective immune response.

\section{Methods}

\section{Vaccine samples}

The DTP vaccines were donated by the Ministries of Health of

*Corresponding author: Oli AN, Department of Pharmaceutical Microbiology and Biotechnology, Faculty of Pharmaceutical Sciences, Nnamdi Azikiwe University, Agulu Campus, Anambra State, Nigeria, E-mail: oli_an@yahoo.com

Received December 21, 2013; Accepted January 25, 2014; Published January 28, 2014

Citation: Oli AN, Agu RU, Nnadozie OJ, Esimone CO (2014) Potency/ Immunogenicity Profile of DPT Vaccines Used in the Expanded Programme on Immunization in South-East, Nigeria. J Vaccines Vaccin 5: 216. doi: 10.4172/21577560.1000216

Copyright: ( 2013 Yousif MA, et al. This is an open-access article distributed under the terms of the Creative Commons Attribution License, which permits unrestricted use, distribution, and reproduction in any medium, provided the original author and source are credited. 
Ebonyi, Enugu and Imo States while Pentavalent (DTP/IPV/Hib) were donated by the Ministries of Health of Abia and Anambra States. Vaccines were transported in vaccines carrier and stored in the storage of facility Nnamdi Azikiwe University Teaching Hospital, Nnewi within 4 hours of collection. Study was conducted within 1 month after vaccine collection. The temperature of the storage facility was charted daily while vaccine storage lasted.

\section{Animals}

Swiss albino mice (15-26 g) were used. They were accommodated under standard conditions (temperature: $26 \pm 2^{\circ} \mathrm{C}$, relative humidity: 45 $\pm 2 \%)$ and provided with standard pellet diet and water. The study was carried out in Pharmacology and Toxicology Laboratory of Faculty of Pharmaceutical Sciences, Nnamdi Azikiwe University, Agulu Campus and in Chemical Pathology laboratory of Nnamdi Azikiwe University Teaching Hospital, Nnewi. The research protocols were approved by the Research and Ethics Committee of Nnamdi Azikiwe University Teaching Hospital, Nnewi.

\section{Antibody development by animal immunization}

Modified Antibody Induction Method in mice [14] was used. Briefly, fourteen mice of similar weight and sex were distributed in to 2 groups with each group containing 7 mice. The first group was immunized with one human dose of the test DPT or Pentavalent vaccine by intra-peritoneal injection. The second group was immunized with DPT vaccine previously stored at $37^{\circ} \mathrm{C}$ for 12 months. The animals were well fed while the study lasted ( 30 days). During the feeding period, the animals were checked daily for any abnormality before they were bled.

\section{Bleeding and serum extraction}

The animals were bled using heparinized capillary tube inserted via the eye (just below the eye ball) and their blood collected in sterile eppendoff tube. The blood was allowed to clot before centrifuging at $4000 \mathrm{rpm}$ for 30 minutes. The sera were carefully pipetted out, transferred into another sterile eppendoff tube and preserved by freezing until ready to use.

\section{Antibody measurement}

Antibody quantifications were carried out using the protocols stated by the manufacturer (Bioactiva Diagnostica GmbH, Homburg, Germany) of the ELISA kits used. All specimens and reagents were allowed to reach room temperature $\left(25 \pm 2^{\circ} \mathrm{C}\right)$. Serum samples/ specimens were diluted carefully mixing $10 \mu \mathrm{l}$ serum $+1 \mathrm{ml}$ of sample diluents. A volume of $100 \mu \mathrm{L}$ of Clostridium tetani $5 \mathrm{~S} \mathrm{IgG}$ or Corynebacterium diphtheriae IgG toxin IgG standards (A-E) and diluted serum samples/specimens containing diphtheria or tetanus antibodies were pipetted into microtitre strip wells pre-coated with inactivated specific Corynebacterium diphtheriae or Clostridium tetani toxin (toxoid) antigens (as the case may be) to bind the antibodies. The samples/specimens were put in duplicate wells and the substrate blank was dispensed into the well A1. The wells were covered with foil supplied in the kits and the plate incubated at $37 \pm 1^{\circ} \mathrm{C}$ for $1 \mathrm{hr} \pm 5$ minutes. The wells were aspirated and washed 5 times for 30 seconds with washing solution $(350 \mu \mathrm{l} /$ well $)$ using automatic microplate washer (Stat Fax - 2600, model \#: H009775). After washing the wells to remove all the unbound sample material, $100 \mu \mathrm{l}$ of $C$. diphtheriae or Clostridium tetani toxin horseradish Peroxidase (HRP) labeled antimouse IgG conjugate was added into all the wells (to bind the captured Corynebacterium diphtheriae or C. tetani toxin-specific antibodies) except the blank well and covered. The plates were incubated for 30 minutes at room temperature $\left(23 \pm 2^{\circ} \mathrm{C}\right)$ away from direct light. Well aspirating and washing was repeated as done previously. The immune complex formed by the bound conjugate was visualized by adding $100 \mu \mathrm{l}$ Tetramethylbenzidine (TMB) substrate which gives a blue reaction product, the intensity of which is proportional to the quantity of Corynebacterium diphtheriae or C. tetani toxin-specific IgG antibodies in the serum/specimen. The colour development is stopped by pipetting $100 \mu \mathrm{l} 0.2 \mathrm{M}$ Sulphuric acid into the wells of the plates. The absorbance at $450 \mathrm{~nm}$ was read using Stat Fax - 2100 microplate reader (manufacturer - Awareness Technology, USA) and the result recorded as mean absorbance. A graph of the absorbance - concentration was developed from the Standards A- E and concentration of the IgG antibody was calculated from the graph.

For the pertussis, $100 \mu \mathrm{L}$ diluted serum samples/specimen and five standards (A - E) of volume $100 \mu \mathrm{l}$ each, were pipetted into microtitre strip wells pre-coated with Bordetella pertussis/toxin (antigen) and incubated at $37 \pm 1^{\circ} \mathrm{C}$ for $1 \mathrm{hr} \pm 5$ minutes. The substrate blank was dispensed into the well $\mathrm{A} 1$, the negative controls into the wells $\mathrm{B} 1$ and $\mathrm{C} 1$, the cut-off controls into wells D1, E1, F1 and G1 while the positive controls were in wells $\mathrm{H} 1$ and A2. The rest of the wells contained the samples in duplicates. The wells were aspirated and washed 5 times for 30 seconds with washing solution $350 \mu \mathrm{l} /$ well using automatic microplate washer (Stat Fax - 2600, model \#: H009775). A volume of $100 \mu \mathrm{l}$ of Bordetella pertussis anti-mouse IgG horseradish peroxidase conjugate was dispensed into all the wells except for the blank well and covered. The plate was incubated for 30 minutes at room temperature $\left(23 \pm 2^{\circ} \mathrm{C}\right)$ away from direct light. Well aspirating and washing was repeated as done previously. Tetramethylbenzidine (TMB) substrate, $100 \mu \mathrm{l}$ volume, was pipetted into all the wells (including the blank well) and the plate was incubated for 15 minutes in the dark at room temperature. Stop solution (0.2M Sulphuric acid) of volume $100 \mu \mathrm{l}$ was pipetted into the wells which changed the colour from blue to yellow. The absorbance was read at $450 \mathrm{~nm}$ using Stat Fax-2100 microplate reader (manufacturer-Awareness Technology, USA) and the result recorded as a ratio of mean absorbance of specimen and the cut-off.

\section{Results}

Table1 shows diphtheria IgG antibody titer in laboratory animals used (mice). It is the recommendation of the manufacturer of the ELISA kit used that titer/results $<0.01 \mathrm{IU} / \mathrm{mL}$ means absence of protective

\begin{tabular}{|c|c|c|c|c|c|c|c|c|c|}
\hline Vaccine from & \multicolumn{7}{|c|}{ ANTIBODY TITER IN THE MICE (IU/mL) } \\
\hline & $\mathbf{1}$ & $\mathbf{2}$ & $\mathbf{3}$ & $\mathbf{4}$ & $\mathbf{5}$ & $\mathbf{6}$ & $\mathbf{7}$ \\
\hline Control & 0.057 & 0.076 & 0.103 & 0.058 & 0.058 & 0.061 & 0.071 & 0.0691 \\
\hline Enugu/Ebonyi & 0.719 & 1.429 & 1.449 & 2.651 & 1.427 & 1.364 & 1.474 & 1.502 & \pm 0.0063 \\
\hline Imo State & 1.179 & 1.109 & 0.954 & 1.294 & 0.872 & 0.700 & 0.904 & 1.002 & \pm 0.2164 \\
\hline Anambra & 0.943 & 1.189 & 1.163 & 0.664 & 0.986 & 1.185 & 0.956 & 1.012 & \pm 0.0713 \\
\hline Abia & 0.637 & 1.109 & 0.969 & 0.664 & 0.897 & 0.823 & 1.452 & 0.9359 & \pm 0.1063 \\
\hline
\end{tabular}

Note: Control was the DPT stored at $37^{\circ} \mathrm{C}$ for 12 months 
antibody level and so immediate full course of basic immunization is recommended. Titers of 0.01-0.09 $\mathrm{IU} / \mathrm{mL}$ means absence of reliable protection (i.e. antibody level is too low). Booster vaccination is recommended within 4-6 weeks. Titers $0.1-1.5 \mathrm{IU} / \mathrm{mL}$ means presence of reliable protection but booster vaccination is needed after 5 years. Titres $>1.5-2.0 \mathrm{IU} / \mathrm{mL}$ means presence of reliable protection but booster vaccination is needed after 7 years while titers $>2.0 \mathrm{IU} / \mathrm{mL}$ mean presence of long term protection but vaccination may be needed after 10 years. All the vaccines from the states have titres between 0.9 and $1.5 \mathrm{IU} / \mathrm{mL}$ and so offer protection.

Table 2 shows pertussis IgG antibody titer in laboratory animals used (mice). The manufacturer of the ELISA kit used recommended a Cut-off of $10 \mathrm{NTU}$ to mean no reliable protection. The antibody level is insufficient to confer protection and so, booster vaccination is needed. A Grey Zone $=9-11$ NTU means that protection is in doubt. Booster vaccination is needed A negative protection $=<9$ NTU meaning no protective antibody and so immediate vaccination is needed. A positive protection $=>11 \mathrm{NTU}$ means there is reliable protection. All the vaccines except the control have antibody titer well above 11 NTU.

Table 3 shows tetanus IgG antibody titer in laboratory animals used (mice). By the recommendations of the manufacturer of the ELISA kit used antibody titer/results $<0.01 \mathrm{IU} / \mathrm{mL}$ $\mathrm{m} \mathrm{e}$ a $\mathrm{n} \mathrm{s}$ absence of protective antibody level. Immediate full course of basic immunization is recommended. Titers $0.01-0.10 \mathrm{IU} / \mathrm{mL}$ means absence of reliable protection (antibody level is too low). Booster vaccination recommended within 4 weeks. Titers $0.11-0.5 \mathrm{IU} / \mathrm{mL}$ means presence of reliable protection but booster vaccination needed after 4-6 weeks. Titers $0.51-1.0 \mathrm{IU} / \mathrm{mL}$ means presence of reliable protection but booster vaccination needed after 2 years. Titers 1.1-5.0 IU/mL means presence of long term protection but control after 5-10 years. Titers $>5.0 \mathrm{IU} / \mathrm{mL}$ means presence of long term protection but control after 10 years. All the vaccines except the control produced titers $>0.10 \mathrm{IU} / \mathrm{mL}$.

In Figure 1 all values are expressed as Mean \pm SEM and $p<0.05$. The control vaccines produced sub-optimal antibody titer (Figure 1).

\section{Discussion}

Storage of the DPT or Pentavalent vaccine outside the recommended temperature for too long is strongly discouraged $[15,16]$. Several reports show that adsorbed vaccines such as DPT stored at freezing temperatures irreversibly loose both their potency and immunogenicity [17-20]. The vaccine from the States' cold stores produced sufficient DPT IgG antibody titers to believe that they have not been stored outside the recommended temperature $\left(2-8^{\circ} \mathrm{C}\right)$. The Tetanus antibody titers (Table 3 ) produced by the vaccines from Enugu/Ebonyi, Imo, Anambra and Abia States were 0.1770, 0.1726, 0.1686 and 0.1759 IU/ $\mathrm{mL}$ respectively and significantly higher than the control (0.0761 IU/ $\mathrm{ml})$. The pertussis IgG antibody evoked by the vaccines from the States was $20.453,21.463,19.633$ and $19.896 \mathrm{NTU} / \mathrm{mL}$ (Table 2) which is also higher than that of the control vaccine $(8.455 \mathrm{NTU} / \mathrm{mL})$. The Diphtheria antibody titer produced by the vaccine from Enugu/Ebonyi States was higher $(1.502 \mathrm{IU} / \mathrm{mL})$ than the antibodies from the rest of the States $1.002,1.012$ and $0.9359 \mathrm{IU} / \mathrm{mL}$ respectively for Imo, Anambra and Abia States (Table 1). The control produced much less antibodies. Figure 1 above shows a graphic presentation of the antibody titers evoked by the DPT/Pentavalent vaccines. It was observed that the control vaccines did not produce enough DPT antibodies, their potency and immunogenicity being compromised by the storage temperature. Oneway analysis of variance shows that the mean antibodies titers evoked by the vaccines differ significantly at $\alpha<0.05$ ( $P$ value $<0.0001$ for all the DPT components) while Bartlett's test for equal variances show that the variances differ except for Pertussis component which has a $\mathrm{P}$ value of 0.6184. The Bartlett's test $P$ values for Tetanus and Diphtheria antibody titers were each $<0.0001$. Dunnett's Multiple Comparison Test shows that the mean antibodies titers for the components of the vaccines differ significantly from the titers evoked by the control vaccines.

\section{Conclusion}

There is statistical difference in the antibody titer evoked by the control compared to that evoked by the vaccines from the states. The vaccines from the States' central cold-chain stores show $100 \%$ potency and immunogenicity. This indicates adequate cold-chain maintenance and monitoring of the storage facilities at these Central Stores in South-east Nigeria. Continuous monitoring of efficiency of cold- chain maintenance and vaccine potency testing would translate to good vaccine strategy [21-23]. The vaccines from the States do not differ significantly from each other on the level of antibody titer (protection) and their individual protection can last for the maximum number of days needed for a repeat vaccination except for the control.

The scientific insight provided in this study is the systematic way of monitoring the efficiency of cold-chain system for vaccine storage and vaccine potency testing which will translate to good vaccine strategy.

\section{Study Limitation}

The cold stores for the States are usually in the cities and are fitted with stand-by generators (alternative power supply). The result of this study therefore may not have reflected the state of these vaccines at the Local Government and end-use stores. It is therefore recommended that this study be replicated with samples from these two sources.

\section{Acknowledgment}

This research was funded by an African Doctoral Dissertation Research Fellowship award offered by African Population and Health Research Center (APHRC) in partnership with the International Development Research Centre (IDRC) and with support from Canadian Commonwealth Scholarship Program (CCSP) administered by the Canadian Bureau for International Education (CBIE) with funding from the Government of Canada's Department of Foreign Affairs and International Trade (DFAIT). The States' ministries of Health donated the vaccines. This study is part of the doctorial research work being undertaken by Oli AN.

\begin{tabular}{|c|c|c|c|c|c|c|c|c|c|}
\hline Vaccine from & & & n & NTIBOD & IN NTU & & & & \\
\hline & 1 & 2 & 3 & 4 & 5 & 6 & 7 & Mean & \pm SEM \\
\hline Control & 5.006 & 11.704 & 7.067 & 12.440 & 7.582 & 3.828 & 11.557 & 8.455 & \pm 1.309 \\
\hline Enugu/Ebonyi & 17.740 & 18.476 & 20.169 & 24.807 & 23.629 & 17.740 & 20.611 & 20.453 & \pm 1.072 \\
\hline Imo State & 20.979 & 24.660 & 20.022 & 19.065 & 24.660 & 23.114 & 17.740 & 21.463 & \pm 1.036 \\
\hline Anambra & 17.814 & 18.255 & 19.654 & 21.494 & 17.740 & 21.273 & 21.200 & 19.633 & \pm 0.644 \\
\hline Abia & 20.169 & 25.985 & 18.550 & 17.667 & 18.108 & 18.623 & 20.169 & 19.896 & \pm 1.078 \\
\hline
\end{tabular}

Note: Control was the DPT stored at $37^{\circ} \mathrm{C}$ for 12 months

Calculated Antibody Titer (in "Nephelometric Turbidity Unit" (NTU)) = Sample (mean) absorbance Value x 10/Cut-off

Table 2: Pertussis lgG Antibody quantification in immunized Mice. 


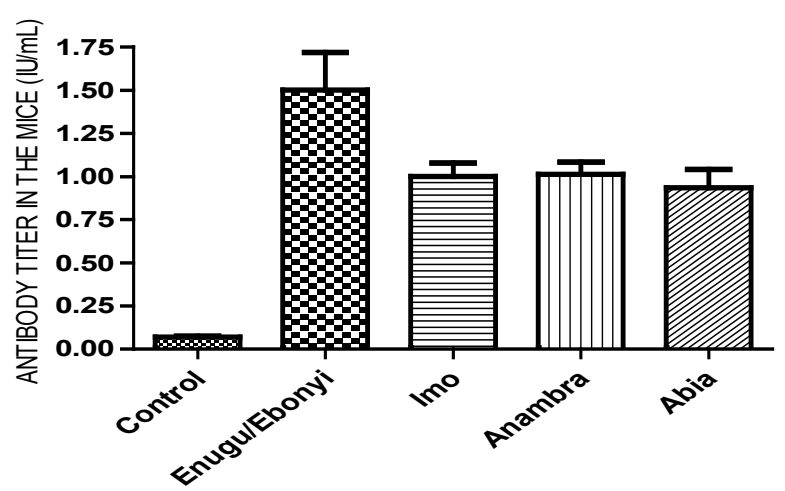

\section{Diphtheria}

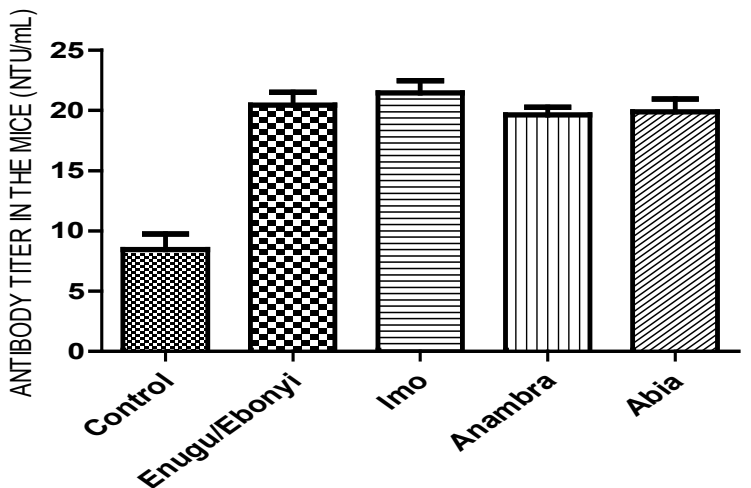

Pertussis

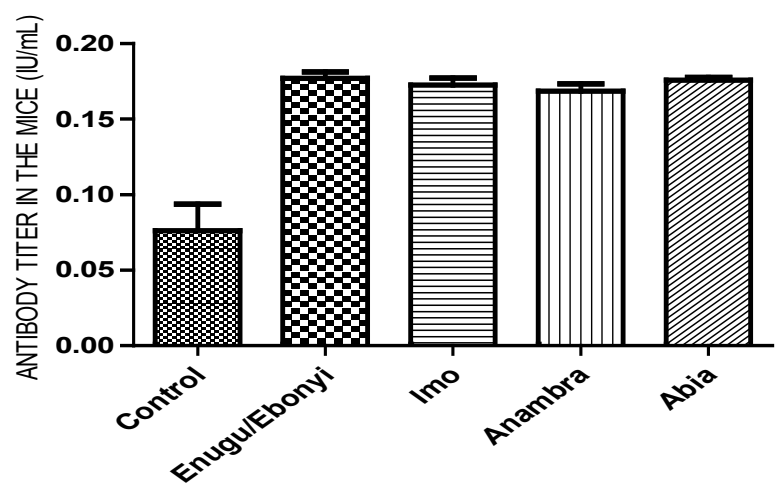

Tetanus

Figure 1: Diphtheria/Pertussis/Tetanus (DPT) Vaccines IgG Antibodies Concentration in immunized mice.

\begin{tabular}{|c|c|c|c|c|c|c|c|c|c|}
\hline \multirow[t]{2}{*}{ Vaccine from } & \multicolumn{8}{|c|}{ ANTIBODY TITER IN THE MICE (IU/mL) } & \multirow[b]{2}{*}{ \pm SEM } \\
\hline & 1 & 2 & 3 & 4 & 5 & 6 & 7 & Mean & \\
\hline Control & 0.103 & 0.103 & 0.104 & 0.103 & 0.104 & 0.009 & 0.007 & 0.0761 & \pm 0.0176 \\
\hline Enugu/Ebonyi & 0.165 & 0.177 & 0.174 & 0.193 & 0.165 & 0.174 & 0.191 & 0.1770 & \pm 0.0042 \\
\hline Imo State & 0.180 & 0.196 & 0.163 & 0.164 & 0.161 & 0.175 & 0.169 & 0.1726 & \pm 0.0047 \\
\hline Anambra & 0.165 & 0.160 & 0.172 & 0.195 & 0.168 & 0.155 & 0.165 & 0.1686 & \pm 0.0049 \\
\hline Abia & 0.173 & 0.181 & 0.172 & 0.170 & 0.175 & 0.184 & 0.176 & 0.1759 & \pm 0.0019 \\
\hline
\end{tabular}

Note: Control was the DPT stored at $37^{\circ} \mathrm{C}$ for 12 months.

Table 3: Tetanus IgG Antibody Quantification in immunized Mice. 
Citation: Oli AN, Agu RU, Nnadozie OJ, Esimone CO (2014) Potency/lmmunogenicity Profile of DPT Vaccines Used in the Expanded Programme on Immunization in South-East, Nigeria. J Vaccines Vaccin 5: 216. doi: 10.4172/2157-7560.1000216

Page 5 of 5

\section{Ethical Issues}

The work described in this article was approved by the Ethics Committee of Nnamdi Azikiwe University Teaching Hospital, Nnewi (Approval \#: NAUTH/CS/66/ Vol.4/220)

\section{Authors' Contribution}

Oli AN wrote the first draft of the manuscript, designed and implemented the study as well as did data analysis and interpretations, Agu RU revised the draft critically and cross-checked for important intellectual content, Nnadozie OJ helped in data acquisition while Esimone $\mathrm{CO}$ conceptualized the study and also revised the manuscript critically.

\section{References}

1. Akumu AO, English M, Scott JA, Griffiths UK (2007) Economic evaluation of delivering Haemophilus influenzae type $b$ vaccine in routine immunization services in Kenya. Bull World Health Organ 85: 511-518.

2. IAVI (2012) China: Estimating the Impact of an AIDS Vaccine.

3. Unicef (2013) Immunization Facts and Figures April 2013.

4. Ministry of Health and Family Welfare, Government of India (2012) Pentavalent Vaccine: Guide for Health Workers with Answers to Frequently Asked Questions.

5. Sharma Monika, Brahmne Hemant, Bafna Pallavi (2011) Potency Testing of Novel DTP Group of Vaccines; Pharmacie Globale. IJCP11: 1-9.

6. Chapman HD, Roberts B, Shirley MW, Williams RB (2005) Guidelines for evaluating the efficacy and safety of live anticoccidial vaccines, and obtaining approval for their use in chickens and turkeys. Avian Pathol 34: 279-290.

7. Apostol Izydor, Kelner Drew N (2008) Managing the Analytical Lifecycle for Biotechnology Products: A Journey from Method Development to Validation, Part One. BioProcess International 12-19.

8. World Health Organization 2012; Recommendations to assure the quality, safety and efficacy of DT-based combined vaccines: Replacement of Technical Report Series 800 Annex 2

9. Hendriksen C, Spieser JM, Akkermans A, Balls M, Bruckner L, et al. (1998). Validation of Alternative Methods for the Potency testing of Vaccines:The Report and Recommendations of European Center for the Validation of Alternative Methods, Workshop 31. ATLA 747-761.
10. McCormack PL (2013) DTaP-IPV-Hep B-Hib vaccine (Hexaxim $\left.{ }^{\circledR}\right)$ : a review of its use in primary and booster vaccination. Paediatr Drugs 15: 59-70.

11. Nunes MC, Madhi SA (2013) Review of a new fully liquid, hexavalent vaccine: Hexaxim. Expert Opin Biol Ther 13: 575-593.

12. http://informahealthcare.com/doi/pdf/10.1517/14712598.2013.774368

13. Ministry of Health and Family Welfare (2010) Handbook for Vaccine \& Cold Chain Handlers, New Delhi.

14. Unicef Dominican Republic: Health - Immunisation and Pentavalent Vaccine

15. Singh GN (2007) Diphtheria and Tetanus and Whole cell Pertussis Vaccine (Adsorbed). Indian Pharmacopoeia 3: 744-757.

16. World Health Organization (2006) Temperature sensitivity of vaccines Immunization, Vaccines and Biological.

17. Ministry of Healthcare and Nutrition-Epidemiology Unit (2011) Cold Chain Management- Part 1. WER, Sri Lanka 38: 1-4.

18. Dietz V, Milstien JB, van Loon F, Cochi S, Bennett J (1996) Performance and potency of tetanus toxoid: implications for eliminating neonatal tetanus. Bull World Health Organ 74: 619-628.

19. Dietz V, Galazka A, van Loon F, Cochi S (1997) Factors affecting the immunogenicity and potency of tetanus toxoid: implications for the elimination of neonatal and non-neonatal tetanus as public health problems. Bull World Health Organ 75: 81-93.

20. Boros CA, Hanlon M, Gold MS, Roberton DM (2001) Storage at -3 degrees $\mathrm{C}$ for $24 \mathrm{~h}$ alters the immunogenicity of pertussis vaccines. Vaccine 19: 3537 3542 .

21. Edstam JS, Dulmaa N, Nymadawa P, Rinchin A, Khulan J, et al. (2002) Comparison of hepatitis $B$ vaccine coverage and effectiveness among urban and rural Mongolian 2-year-olds. Prev Med 34: 207-214.

22. Confidence $P$, Vaccine Safety - The Centers for Disease Control and Prevention pp 45-60.

23. American Academy of Pediatrics (2009) Vaccine Safety and Contraindications (28thedn). Elk Grove Village, IL, USA 